\title{
Response of Yield and Related Attributes of Upland Cotton to Weather Variables
}

\author{
Kalim Ullah1, Muhammad Idrees Khan², Zahid Mahmood², Toheed Iqbal'3 , Saeed Muhammad², \\ Hafiz Abdul Haq², Aftab Ahmad', Sabahat Hussain²
}

${ }^{1}$ The PCCC, Cotton Research Station, Dera Ismail Khan, Pakistan

${ }^{2}$ The PCCC, Central Cotton Research Institute, Multan, Pakistan

${ }^{3}$ Agricultural Research Institute, Ratta Kulachi, Dera Ismail Khan, Pakistan

${ }^{4}$ Global Change Impact Study Centre Islamabad, Islamabad, Pakistan

Email: peer60000@gmail.com

How to cite this paper: Ullah, K., Khan, M.I., Mahmood, Z., Iqbal, T., Muhammad, S., Haq, H.A., Ahmad, A. and Hussain, S. (2017) Response of Yield and Related Attributes of Upland Cotton to Weather Variables. American Journal of Plant Sciences, 8, 1711-1720.

https://doi.org/10.4236/ajps.2017.87118

Received: May 29, 2017

Accepted: June 25, 2017

Published: June 29, 2017

Copyright (® 2017 by authors and Scientific Research Publishing Inc. This work is licensed under the Creative Commons Attribution International License (CC BY 4.0).

http://creativecommons.org/licenses/by/4.0/

\begin{abstract}
Cotton growth and development is effected by various ecological issues like temperature fluctuations, distribution and quantity of rainfall, relative humidity and winds which are the climate change attributes. A field experiment was carried out to find out the response of cotton to weather variables in terms of total variation in yield and quality. The effect of planting times and thermal temperatures (cumulative heat units) on yield of 4 cotton cultivars viz; CIM600, CIM-616, CIM-622 \& CRIS-641 was evaluated. Plants were sown on 6 planting times during the year 2015-2016 and 2016-2017 in an experiment conducted in randomized complete block design having three replications. Cotton cultivars depicted significant variances for number of bolls plant ${ }^{-1}$, boll weight and seed cotton yield. The cultivar CIM-616 depicted the highest seed cotton yield of $2083.60 \mathrm{~kg} \cdot \mathrm{ha}^{-1}$ on interpretation of highest bolls and boll weight. Maximum seed cotton yield was noted in planting time from $1^{\text {st }}$ April to $15^{\text {th }}$ April whereas early and late planting decreases the seed cotton yield on account of less accretion of cumulative heat units. Regression analysis depicted that rise of one unit (15 days) from early to optimal date $\left(15^{\text {th }}\right.$ March to $15^{\text {th }}$ April) enhanced the seed cotton yield by $93.76 \mathrm{~kg} \cdot \mathrm{ha}^{-1}\left(\mathrm{y}=-93.764 \mathrm{x}^{2}+\right.$ $521.04 x+1364)$. Delayed planting also reduces the seed cotton yield with the same ratio. It is therefore established that cotton must be cultivated from $1^{\text {st }}$ April to $1^{\text {st }}$ May to harvest good production in this type of climate.
\end{abstract}

\section{Keywords}

G. hirsutum, Planting Time, Cumulative Heat Units, Cotton Cultivars

\section{Introduction}

The global climate has not only changed due to the increase in $30 \%$ of the Car- 
bon dioxide $\left(\mathrm{CO}_{2}\right)$ which is a major greenhouse effecting increase in temperature from $0.3^{\circ} \mathrm{C}-0.6^{\circ} \mathrm{C}[1]$. The agriculture sector has the potential to take the edge off climate change mainly by increasing the carbon rate at which it is stored in the soil. In case of climate change, in $21^{\text {st }}$ century we are expecting important changes in crop production. If the temperature on the global surface is changed with radioactive, it will change in environment with physiological effect [2]. The meteorologist in the current scenario predicts the increase in global mean temperature from $0.9^{\circ} \mathrm{C}$ to $3.5^{\circ} \mathrm{C}$ up to the year 2100 . Therefore, food and fibre production in such high-temperature and humid environments may be more limited. And this will be inadequate to vegetative structures as well as to the animals that consume these vegetative structures if, global climate has changed as predicted [2]. Lower emission of the $\mathrm{CO}_{2}$ and greenhouse gas will lessen the magnitude of climate change, its impact and the rate at which they appears [3].

Cotton crop is more sensitive to environmental stresses result in progressive decrease in yield on the temperature above the optimum. Moreover in most of the cotton belts during the flowering stage and boll formation the temperature is already above the optimum and further increase will cause reduction in the yield of this crop [4]. Furthermore, moisture deficits can also depressed the lint of cotton in majority of the cotton producing areas [5].

Pakistanis likely to be the country that will suffer most from climate change as far as agriculture and cotton production are concerned. On the bases of cotton production and consumption Pakistan placed $4^{\text {th }}$ and $3^{\text {rd }}$ each with a $10 \%$ share respectively in the world. The main cotton producing provinces are the Punjab with a share of about $79 \%$ and Sindh having an area of $20 \%$ under cotton cultivation. The cotton belt prolongs about $1200 \mathrm{~km}$ along the Indus River and its offshoots [6]. The Indus River is very important to agriculture in Pakistan and cotton production is totally dependent on irrigation with water from this river. But due to the lessening in the size of the Himalayan and Tibetan glaciers and snowfields, it will carry less water which will automatically cause in the reduction of cotton yield. Furthermore, with respect to high temperatures cotton production in this region already takes place in sub-optimal conditions. Further increases in temperature will disheartened the seed cotton yield during the growing season [6]. In Pakistan cotton crop is growing mostly in low rainfall and high temperature under semi-arid and irrigated conditions. This crop due to its vertical tap root system is mostly tolerant to high temperature but very high temperature makes it vulnerable to the pest attack [7]. And the response of this crop towards the vegetative growth and fruiting parts is loss and up to some extent to water stress condition. But it is more sensitive to excessive water availability because more water can cause reduction in yield and fibre qualities during the stage of its flowering and boll formation [7].

In this context the objectives of the study were to find out the impact of planting times on seed cotton yield by providing different weather conditions and modelling an association between heat units accumulation. 


\section{Material and Methods}

\subsection{Experimental Location and Plant Materials}

Two year field experiment was carried out at Cotton Research Station, D. I. Khan (situated at $31^{\circ} 49^{\prime} \mathrm{N}$ latitude and $70^{\circ} 55^{\prime} \mathrm{E}$ longitude) during the crop season 2015-2016 and 2016-2017. Four cultivars viz., CIM-600, CIM-616, CIM-622, and CRIS-641 were investigated during the study. These cultivars were cultivated at various times in order to generate variation in temperature, humidity and heat units for growth, development and maturity, thus providing an extensive choice of various weather variables from planting till maturity. The climatological statistics was collected from Arid Zone Research Centre (AZRC), PARC, D. I. Khan. The baseline temperature for cumulative heat units (CHU)/ growing degree days (GDD) calculation was $16^{\circ} \mathrm{C}$. The $\mathrm{CHU}$ for different phases were calculated via the equation as outlined by Dwyer and Stewart [8].

$$
\mathrm{CHU}=\frac{\left(T_{\max }+T_{\min }\right)-T_{b}}{2}
$$

where, $T_{\max }, T_{\min }$ and $T_{\mathrm{b}}$ are maximum, minimum and baseline temperatures respectively below which development ceases.

The soil of the experimental site was bit saline in nature and less fertile having electrical conductivity of $2.66 \mathrm{dS} \cdot \mathrm{m}^{-1}, \mathrm{pH}$ of 7.90 , organic matter $0.87 \%$, sand 151 $\mathrm{g} \cdot \mathrm{kg}^{-1}$, silt $451 \mathrm{~g} \cdot \mathrm{kg}^{-1}$, clay $400 \mathrm{~g} \cdot \mathrm{kg}^{-1}$ and total $\mathrm{N} 0.99 \mathrm{~g} \cdot \mathrm{kg}^{-1}$.

\subsection{Experimental Environments}

The trial was carried out at 12 environments $(2$ years $\times 6$ sowing times) (Table 1).

Table 1. Twelve manipulated environments used in the study.

\begin{tabular}{ccc}
\hline Environment & Cropping season & Planting date \\
\hline E1 & $2015-2016$ & $15^{\text {th }}$ March \\
E2 & $2015-2016$ & $1^{\text {st }}$ April \\
E3 & $2015-2016$ & $15^{\text {th }}$ April \\
E4 & $2015-2016$ & $1^{\text {st }}$ May \\
E5 & $2015-2016$ & $15^{\text {th }}$ May \\
E6 & $2015-2016$ & $1^{\text {st }}$ June \\
E7 & $2016-2017$ & $15^{\text {th }}$ March \\
E8 & $2016-2017$ & $1^{\text {st }}$ April \\
E9 & $2016-2017$ & $15^{\text {th }}$ April \\
E10 & $2016-2017$ & $1^{\text {st }}$ May \\
E11 & $2016-2017$ & $15^{\text {th }}$ May \\
E12 & $2016-2017$ & $1^{\text {st }}$ June \\
\hline
\end{tabular}




\subsection{Experimental Layout and Crop Management}

The four cotton cultivars (CIM-600, CIM-616, CIM-622, CRIS-641) were sown at 6 diverse planting times in the cropping year 2016 and 2017. These cultivars were sown in randomized complete block (RCB) design having 3 replications. Sowing was done in a four row subplot having $10 \mathrm{~m}$ length and a spacing of 0.75 $\mathrm{m}$ between and $0.30 \mathrm{~m}$ within the hills. Seeds were cultivated in hills having 5 seed which was immediately irrigated. $60 \mathrm{~kg} \cdot \mathrm{ha}^{-1}$ of phosphorus in the form of single super phosphate and $50 \mathrm{~kg} \cdot \mathrm{ha}^{-1}$ of $\mathrm{N}$ as urea were used before sowing and $50 \mathrm{~kg} \cdot \mathrm{ha}^{-1} \mathrm{~N}$ as urea at flowering and $50 \mathrm{~kg} \cdot \mathrm{ha}^{-1}$ at boll formation stage. 20 days after sowing, seedlings were thinned to single plant per hill. Picking was performed after 130 and 150 days of sowing. All the agronomic and plant protection practices were performed as per recommendations.

List of genotypes used in the study.

\begin{tabular}{|c|c|c|c|}
\hline \multicolumn{4}{|c|}{ Name of genotypes and their origin and their salient characters } \\
\hline CIM-600 & CIM-616 & CIM-622 & CRIS-641 \\
\hline (Origin) & (Origin) & (origin) & (origin) \\
\hline CIM-555 × Bt.CIM-598 & (Bt.CIM-592 × CIM-443) & CIM-554×IR-1524 & FH-1000 × NIAB-999 \\
\hline \multicolumn{4}{|c|}{ Representative characters } \\
\hline Higher yield & Possess good yield & Good yield potential & Higher yield potential \\
\hline Good fibre traits & Excellent fibre characters & Better fibre traits & Big boll weight \\
\hline High GOT & Higher lint percentage & $\begin{array}{l}\text { Higher ginning } \\
\text { out turn }\end{array}$ & $\begin{array}{l}\text { Higher lint } \\
\text { percentage }\end{array}$ \\
\hline $\begin{array}{l}\text { Suitable for timely } \\
\text { planting of wheat }\end{array}$ & Heat tolerant, very early & $\begin{array}{l}\text { Heat tolerant and } \\
\text { early maturity }\end{array}$ & $\begin{array}{l}\text { Excellent fibre } \\
\text { characters }\end{array}$ \\
\hline $\begin{array}{l}\text { Wider adoptability } \\
\text { and drought tolerant }\end{array}$ & $\begin{array}{c}\text { Drought tolerant } \\
\text { and wider adoptability }\end{array}$ & $\begin{array}{c}\text { Drought tolerant and } \\
\text { wider adoptability }\end{array}$ & $\begin{array}{c}\text { Heat and } \\
\text { drought tolerant }\end{array}$ \\
\hline $\begin{array}{l}\text { Hairy and tolerant } \\
\text { to Jassids attacks }\end{array}$ & $\begin{array}{l}\text { Hairy and tolerant } \\
\text { to attack of Jassids }\end{array}$ & $\begin{array}{l}\text { Hairy and tolerant } \\
\text { to attack of Jassids }\end{array}$ & Wider adoptability \\
\hline $\begin{array}{l}\text { Good opining and } \\
\text { big boll size }\end{array}$ & $\begin{array}{l}\text { Good boll size } \\
\text { and good opening }\end{array}$ & $\begin{array}{l}\text { Very good opening } \\
\text { and big boll }\end{array}$ & $\begin{array}{l}\text { Good boll size and } \\
\text { very good opening }\end{array}$ \\
\hline Spin on higher count & Spin on higher count. & $\begin{array}{l}\text { Ability to spin } \\
\text { on higher count }\end{array}$ & Sympodial plant type \\
\hline
\end{tabular}

\subsection{Recording of Observations and Statistical Analysis}

Data on number of bolls plant ${ }^{-1}$, boll weight $(\mathrm{g})$ and seed cotton yield $\left(\mathrm{kg} \cdot \mathrm{ha}^{-1}\right)$ were recorded. The data recorded were subjected to analysis of variance technique appropriate for RCB design as suggested by Steel et al. [9]. After having homogeneity test for error variances by using Bartlett's tests [10], combined analysis of variance was performed. To determine the statistical differences in means, least significant difference (LSD) test at $5 \%$ level of probability was used when the F value was significant. For this purpose, MSTATC [11] statistical package was utilized. For diagrams and regression analysis [9], Microsoft excel 2007 was used. 


\section{Results and Discussion}

\subsection{Combined Analysis of Variance}

Combined analysis of variance depicted significant $(P \leq 0.01)$ differences among genotypes (G) and planting times (D) for number of bolls, boll weight and seed cotton yield (Table 2) presenting the incidence of variation amongst the genotypes in addition to environments. Furthermore, it proposes that some of the genotypes were superior to others in these studied traits. Significant mean squares of genotypes also depicted higher genetic variability among the tested genotypes. This variation was recorded for all the studied attributes which can be used as a valuable breeding source for several purposes. The $\mathrm{G} \times \mathrm{D}$ interaction was also significant $(P \leq 0.05)$ for boll weight indicating that various genotypes performed differently in different environments (Table 2). It further indicates significant genotype $\times$ environment interaction. It can be thus concluded that in cotton breeding program, environmental effects in understanding plant growth must be given due consideration. These results are in accordance with the findings of Machado et al. [12] and Ullah et al. [13] who also recorded significant genotype $\times$ planting times, genotype $\times$ year and genotype $\times$ year $\times$ location interaction. Significant genotype $\times$ environment interaction in upland cotton was also recorded by Unay et al. [14] and Satish et al. [15]. Similarly significant mean squares for $\mathrm{G}, \mathrm{E}$, and $\mathrm{G} \times \mathrm{E}$ was also recorded for various morphological traits by Khan et al. [16] and Gul [17].

\subsection{Number of Bolls Plant ${ }^{-1}$}

Number of bolls plant ${ }^{-1}$ plays a key role in managing the differences in seed cotton yield on account of the reason that it is the major independent yield component. Hence in cotton improvement selection for more number of bolls plant ${ }^{-1}$ must receive due emphasis. Analysis of variance revealed that planting times significantly $(P \leq 0.01)$ affected the number of bolls plant ${ }^{-1}$ (Table 3$)$. Number of bolls plant ${ }^{-1}$ increased with delay in planting time and more number of bolls

Table 2. Combined analysis of variance for studied crop phenology and yield components of four cotton genotypes evaluated for two years and six planting dates.

\begin{tabular}{|c|c|c|c|c|}
\hline Source of variability & $\mathrm{DF}$ & $\begin{array}{l}\text { Number of } \\
\text { bolls plant }^{-1}\end{array}$ & $\begin{array}{c}\text { Boll weight } \\
\text { (g) }\end{array}$ & $\begin{array}{c}\text { Seed cotton } \\
\text { yield }\left(\mathrm{kg} \cdot \mathrm{ha}^{-1}\right)\end{array}$ \\
\hline Years (Y) & 1 & $1764.00^{* *}$ & $0.962^{\star *}$ & $3077101^{* *}$ \\
\hline Planting dates (D) & 5 & $241.13^{\star *}$ & $0.606^{\star *}$ & $3118491^{\star \star}$ \\
\hline $\mathrm{Y} \times \mathrm{D}$ & 5 & $35.08^{\star \star}$ & $0.221^{\star *}$ & $255097^{\star *}$ \\
\hline Genotypes (G) & 3 & $211.38^{\star *}$ & $0.662^{\star *}$ & $1647814^{\star *}$ \\
\hline $\mathrm{Y} \times \mathrm{G}$ & 3 & $55.54^{* *}$ & $0.309^{\star *}$ & $376002^{* *}$ \\
\hline $\mathrm{D} \times \mathrm{G}$ & 15 & 1.69 & $0.010^{*}$ & 31957 \\
\hline $\mathrm{Y} \times \mathrm{D} \times \mathrm{G}$ & 15 & 2.26 & 0.0079 & 18013 \\
\hline Error $(\mathrm{R} \times \mathrm{Y} \times \mathrm{D} \times \mathrm{G})$ & 94 & 1.41 & 0.0087 & 26049 \\
\hline
\end{tabular}

${ }^{\star},{ }^{*}$ significant at $5 \%$ and $1 \%$ level of probability respectively, using the $\mathrm{F}$ test. 
Table 3. Means of six planting dates and four cotton genotypes for some of the studied traits.

\begin{tabular}{ccccc}
\hline Factor & Treatment & $\begin{array}{c}\text { Number of } \\
\text { bolls plant }\end{array}$ & $\begin{array}{c}\text { Boll weight } \\
(\mathrm{g})\end{array}$ & $\begin{array}{c}\text { Seed cotton } \\
\text { yield }\left(\mathrm{kg}^{-1} \mathrm{ha}^{-1}\right)\end{array}$ \\
\hline Planting dates & $15^{\text {th }}$ March & $18.83 \mathrm{c}$ & $2.58 \mathrm{c}$ & $1792.50 \mathrm{c}$ \\
& $1^{\text {st }}$ April & $21.50 \mathrm{~b}$ & $2.80 \mathrm{~b}$ & $2026.00 \mathrm{ab}$ \\
& $15^{\text {th }}$ April & $23.17 \mathrm{a}$ & $2.91 \mathrm{a}$ & $2096.70 \mathrm{a}$ \\
& $1^{\text {st }}$ May & $20.79 \mathrm{~b}$ & $2.78 \mathrm{~b}$ & $1926.00 \mathrm{bc}$ \\
LSD $_{0.05}$ & $15^{\text {th }}$ May & $17.71 \mathrm{~d}$ & $2.64 \mathrm{c}$ & $1643.00 \mathrm{~d}$ \\
Genotypes $^{\text {st }}$ & & $14.25 \mathrm{e}$ & $2.48 \mathrm{~d}$ & $1109.30 \mathrm{e}$ \\
& CIM-600 & $18.33 \mathrm{bc}$ & $2.57 \mathrm{c}$ & $1630.80 \mathrm{~b}$ \\
& CIM-616 & $22.97 \mathrm{a}$ & $2.89 \mathrm{a}$ & $2083.60 \mathrm{a}$ \\
& CIM-622 & $18.50 \mathrm{~b}$ & $2.66 \mathrm{~b}$ & $1698.89 \mathrm{~b}$ \\
& CRIS-641 & $17.69 \mathrm{c}$ & $2.66 \mathrm{~b}$ & $1649.10 \mathrm{~b}$ \\
& & 0.73 & 0.057 & 99.51 \\
\hline
\end{tabular}

Means followed by similar letters in the same column are not significantly different at $5 \%$ level of probability.

plant $^{-1}$ (23.17) was recorded in the crop sown on $15^{\text {th }}$ April whereas further delay in planting reduced the number of bolls plant ${ }^{-1}$ and thus minimum was recorded in the crop planted either very early (18.83) on $15^{\text {th }}$ March or delayed (14.25) on $1^{\text {st }}$ June. This reduction in number of bolls plant ${ }^{-1}$ in early and delayed planting might be attributed to the variation in temperature prevailed by the crop growth. The genotypes studied also bared different number of bolls plant ${ }^{-1}$. The mean comparison of the genotypes depicted significant differences at $5 \%$ probability and thus CIM-616 has the maximum (22.97) number of bolls plant ${ }^{-1}$ followed by CIM-622 (18.50) while the lowest was recorded in genotype CRIS-641 (17.69).

\subsection{Boll Weight (G)}

Statistical analysis of the data depicted significant differences $(P \leq 0.01)$ in boll weight among various planting times. Maximum boll weight of $2.91 \mathrm{~g}$ was recorded in a crop sown on $15^{\text {th }}$ April which was followed by the crop planted on $1^{\text {st }}$ April (2.80 g) or $1^{\text {st }}$ May (2.78 g) (Table 3). Boll weight enhanced with delayed planting time from $15^{\text {th }}$ March to $15^{\text {th }}$ April. However further delay in planting reduced the boll weight which might be due to unfavourable photoperiod and high temperature at early growth and development stage that forced the crop to end up the life cycle rapidly at the cost of reduction in yield and yield related attributes. Different genotypes also produced significantly different boll weight. Highest boll weight of $2.89 \mathrm{~g}$ was recorded in CIM-616 which was followed by CIM-622 and CRIS-641 (Table 3). Seed cotton yield in cotton was highly affected directly and indirectly both by boll numbers and boll weight [18] [19]. 


\subsection{Seed Cotton Yield (kg.ha-1)}

Planting times and suitable genotypes plays the most significant role in yield and yield related components. The cotton crop planted on $15^{\text {th }}$ April depicted maximum seed cotton yield of $2096.70 \mathrm{~kg} \cdot \mathrm{ha}^{-1}$ on account of having maximum number of bolls plant ${ }^{-1}$ boll weight, and most favourable environmental conditions in comparison to other planting times investigated in the study. The crop planted on $1^{\text {st }}$ April ranked second with $2026 \mathrm{~kg} \cdot \mathrm{ha}^{-1}$ regarding the seed cotton yield (Table 3). It is evident from the table that planting times and genotypes significantly influenced the seed cotton yield. The seed cotton yield enhanced from 1792.50 to $2096.70 \mathrm{~kg} \cdot \mathrm{ha}^{-1}$ as planting time delayed from $15^{\text {th }}$ March to $15^{\text {th }}$ April while further delay in planting time reduced the seed cotton yield and delayed planting from $15^{\text {th }}$ April to $1^{\text {st }}$ June reduced the seed cotton yield to 1109.30 $\mathrm{kg} \cdot \mathrm{ha}^{-1}$ reflecting $304.20 \mathrm{~kg} \cdot \mathrm{ha}^{-1}$ increment up to $15^{\text {th }}$ April and then 987.40 $\mathrm{kg} \cdot \mathrm{ha}^{-1}$ decrements in seed cotton yield respectively (Table 3 ). Determination of optimum planting time and suitable cultivar for certain region is the major agronomic factor and utmost important to obtain higher seed cotton yield. The yielding ability of the present genotypes was also the result of the different interaction $(D \times G, G \times Y, D \times G \times Y)$ factors [16]. Different growing conditions resulted in variation in seed cotton yield from year to year variation. Both genotypes and environment contributed to the variation in seed cotton yield however the environmental complex depicted primary yield effects in comparison to genotypes [20] [21]. The finding of the present study was also in accordance with and the environmental factor was predominant for the yield variation.

Significant difference was also observed for seed cotton yield among different genotypes. The maximum seed cotton yield of $2083.60 \mathrm{~kg} \cdot \mathrm{ha}^{-1}$ was recorded for CIM-616 which was followed by CIM-622 (Table 3). Cotton genotypes revealed significant differences through various environments and their interaction for seed cotton yield, indicating considerable variation among genotypes as well as environments [14] [17].

Regression analysis of planting time and seed cotton yield also depicted significant relation between these two attributes. Besides, $\mathrm{R}^{2}$ (coefficient of determination) revealed that up to $99 \%$ of the increase till $15^{\text {th }}$ April and later on decrease in seed cotton yield might be due to the influence of planting time. The regression between seed cotton yield and planting time was negative and regression analysis suggested that increase in one unit (15 days) of planting time increased/decreased seed cotton yield by $93.76 \mathrm{~kg} \cdot \mathrm{ha}^{-1}$ (Figure 1).

Environmental factor, particularly temperature was the main attribute that influenced the plant growth and development. Significant variation among genotypes regarding growing degree days were recorded which explained that different genotypes have different maturing period. Accumulation of maximum growing degree days/heat units for the $15^{\text {th }}$ April and $1^{\text {st }}$ May planting during both the years provided a clue that $15^{\text {th }}$ April to $1^{\text {st }}$ May is the best planting time for better cotton crop to harvest good yield (Table 4). The yield of $1^{\text {st }}$ April was also comparable. The accumulation of GDD/CHU determined the yield and 


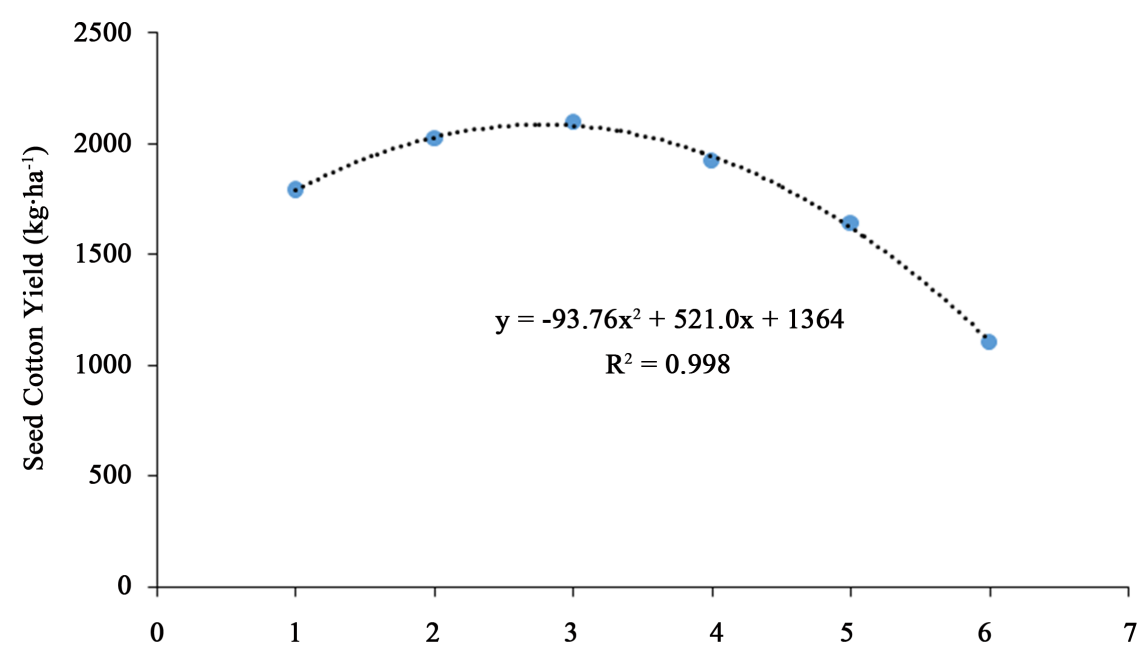

1: 15th March, 2: 1st April, 3: 15th April, 4: 1st May, 5: 15th May, 6: 1st June

Figure 1. Graphical presentation of regression analysis among seed cotton yield and planting dates.

Table 4. Relationship between growing degree days and seed cotton yield $\left(\mathrm{kg} \cdot \mathrm{ha} \mathrm{a}^{-1}\right)$.

\begin{tabular}{ccccc}
\hline \multirow{2}{*}{ Planting dates } & \multicolumn{3}{c}{ Growing degree days } & \multirow{2}{*}{$\begin{array}{c}\text { Seed cotton yield } \\
\left(\mathrm{kg} \cdot \mathrm{ha}^{-1}\right)\end{array}$} \\
\cline { 2 - 4 } & $2015-16$ & $2016-17$ & Mean & $1792.50 \mathrm{c}$ \\
\hline $15^{\text {th }}$ March & 1678.50 & 1663.00 & 1670.75 & $2026.00 \mathrm{ab}$ \\
$1^{\text {st }}$ April & 1876.30 & 1845.50 & 1860.90 & $2096.70 \mathrm{a}$ \\
$15^{\text {th }}$ April & 2183.33 & 2130.50 & 2156.91 & $1926.00 \mathrm{bc}$ \\
$1^{\text {st }}$ May & 2114.34 & 2091.50 & 2102.92 & $1643.00 \mathrm{~d}$ \\
$15^{\text {th }}$ May & 2123.44 & 2116.00 & 2119.72 & $1109.30 \mathrm{e}$ \\
$1^{\text {st }}$ June & 2003.12 & 1982.50 & 1992.81 & 135.55 \\
LSD $_{0.05}$ & & & & \\
\hline
\end{tabular}

Means followed by similar letters are not significantly different at $5 \%$ level of probability.

yield related attributes because temperature is the primary factor which governs the crop growth rate [22].

\section{Conclusion}

The present finding suggested that number of bolls, boll weight and seed cotton yield have been significantly affected by the genotypes and growing conditions under the various planting times. To harvest good output in terms of yield, accumulation of GDD/CHU plays a vital role in modelling cotton to the expected global warming in the future. Variation among cotton attributes might be attributed to temperature based on different climatic conditions prevailed during the crop life cycle. It is thus concluded that $15^{\text {th }}$ April to $1^{\text {st }}$ May is the optimum time and early/delayed planting results in reduction of seed cotton yield as the crop completes its life cycle in short duration, accumulating less heat units. 


\section{References}

[1] Chakaraborty, S., Tiedemann, A.V. and Teng, P.S. (2000) Climate Change: Potential Impact on Plant Diseases. Environmental Pollution, 108, 317-326. https://doi.org/10.1016/S0269-7491(99)00210-9

[2] Reddy, K.R., Hodges, H.F. and Mckinion, M. (1997) A Comparison of Scenarios for the Effect of Global Climate Change on Cotton Growth and Yield. Australian Journal of Plant Physiology, 24, 707-713. https://doi.org/10.1071/PP96138

[3] Karl, T.R., Melillo, J.M. and Peterson, T.C. (2009) Global Climate Change Impacts in the United States. Cambridge University Press, USA.

[4] Sing, R.P., Parsad, P.V.V., Sunita, K., Giri, S.N. and Reddy, K.R. (2007) Influence of High Temperature and Breeding for Heat Tolerance in Cotton: A Review. Advances in Agronomy, 93, 313-385. https://doi.org/10.1016/S0065-2113(06)93006-5

[5] Pettigrew, T.W. (2003) Physiological Consequences of Moisture Deficit Stress in Cotton. Crop Science, 44, 1265-1272. https://doi.org/10.2135/cropsci2004.1265

[6] Ton, P. (2010) Cotton and Climate Change: Impacts and Options to Mitigate and Adapt. Ton Consultancy, Amsterdam.

[7] International Trade Centre (2011) Cotton and Climate Change: Impacts and Options to Mitigate and Adapt. Geneva: ITC, 2011. xii, 32 p. (Technical Paper). Doc. No.MAR-11-200. E.

[8] Dwyer, L.M. and Stewart, D.W. (1986) Leaf Area Development in Field Grown Maize. Agronomy Journal, 78, 334-343.

https://doi.org/10.2134/agronj1986.00021962007800020024x

[9] Steel, R.G.D., Torrie, J.H. and Dickey, D.A. (1997) Principles and Procedures of Statistics: A Biometrical Approach. 3rd Edition, McGraw-Hill, New York.

[10] Snedecor, G.W. and Cochran, W.G. (1983) Statistical Methods. 6th Edition, Oxford and IBH, New Delhi.

[11] Freed, R., Einensmith, S.P., Gutez, S., Reicosky, D., Smail, V.W. and Wolberg, P. (1989) User's Guide to MSTAT-C Analysis of Agronomic Research Experiments. Michigan State University, East Lansing.

[12] Machado, J.R.D.A., Penna, J.C.V., Fallieri, J., Santos, P.G. and Lanza, M.A. (2002) Stability and Adaptability of Seed Cotton Yields of Upland Cotton Genotypes in the State of Minas Gerais, Brazil. Crop Breeding and Applied Biotechnology, 2, 401410. https://doi.org/10.12702/1984-7033.v02n03a10

[13] Ullah, K., Khan, N., Usman, Z., Ullah, R., Saleem, F.Y., Shah, S.A.I. and Salman, M. (2016) Impact of Temperature on Yield and Related Traits in cotton Genotypes. Journal of Integrative Agriculture, 15, 678-683.

https://doi.org/10.1016/S2095-3119(15)61088-7

[14] Unay, A., Basal, H., Erkul, A. and Yuksekkaya, Z. (2004) Stability Analysis of Upland Cotton Genotypes to the Aegean Region in Turkey. Asian Journal of Plant Sciences, 3, 36-38. https://doi.org/10.3923/ajps.2004.36.38

[15] Satish, Y., Jain, P.P. and Chhabra, B.S. (2009) Stability Analysis for Yield and Its Component Traits in American Cotton (G. hirsutum L.). Journal of Cotton Research and Development, 23, 175-182.

[16] Khan, N.G., Naveed, M. and Khan, N.I. (2008) Assessment of Some Novel Upland Cotton Genotypes for Yield Constancy and Malleability. International Journal of Agriculture and Biology, 10, 109-111.

[17] Gul, S. (2013) Genotype by Environment Interaction for Morpho-Yield Traits in Upland Cotton. MS Thesis, The University of Agriculture, Peshawar. 
[18] Khan, N.U. (2013) Diallel Analysis of Cotton Leaf Curl Virus (CLCuV) Disease, Earliness, Yield and Fiber Traits under CLCuV Infestation in Upland Cotton. Australian Journal of Crop Science, 7, 1955-1966.

[19] Batool, S., Khan, N.U., Gul, S., Baloch, M.J., Turi, N.A., Taran, S.A. and Saeed, M. (2013) Genetic Analysis for Yield and Yield Contributing Variables in Upland Cotton. Journal of Food Agriculture and Environment, 11, 624-630.

[20] Best, E.C. (2005) Source-Sink Relations in Cotton: Genetic and Environmental Affectors. MS Thesis, Texas Tech University, Texas, EUA.

[21] Ahmed, A.E., Abdalla, A.H. and Fadlalla, A.S. (2006) A Note on the Stability of Five Medium Staple Cotton ( $G$. hirsutum L.) Varieties for Some Fibre Properties in the Gezira Scheme of the Sudan. University of Khartoum Journal of Agricultural Sciences, 14, 313-319.

[22] Kaleem, S., Hassan, F.U. and Saleem, A. (2009) Influence of Environmental Variations on Physiological Attributes of Sunflower. African Journal of Biotechnology, 8, 3531-3539.

Submit or recommend next manuscript to SCIRP and we will provide best service for you:

Accepting pre-submission inquiries through Email, Facebook, LinkedIn, Twitter, etc. A wide selection of journals (inclusive of 9 subjects, more than 200 journals)

Providing 24-hour high-quality service

User-friendly online submission system

Fair and swift peer-review system

Efficient typesetting and proofreading procedure

Display of the result of downloads and visits, as well as the number of cited articles

Maximum dissemination of your research work

Submit your manuscript at: http://papersubmission.scirp.org/

Or contact ajps@scirp.org 